Scientific Note

\title{
On the occurrence of three new Lycaenid butterflies (Lepidoptera) from Jammu and Kashmir, India
}

Sobre la aparición de tres nuevas mariposas licénidas (Lepidoptera) de Jammu y Cachemira, India

Neeraj Sharma $^{1 *}$ (i) and Shakha Sharma ${ }^{2}$

${ }^{1}$ Institute of Mountain Environment, University of Jammu, Bhaderwah, Jammu \& Kashmir 182222, India. 鸣 nirazsharma@gmail.com. Department of Zoology, Government Gandhi Memorial Science College, Jammu, Jammu E Kashmir 180006, India.

ZooBank: urn:lsid:zoobank.org:pub:EED9FBAD-8DB4-4735-94AA-EEE92842EC25

https: / / doi.org/ 10.35249/ rche.47.2.21.09

Abstract. The present communication deals with three butterfly species belonging to family Lycaenidae and subfamily Theclinae, recorded for the first time from different localities in a mountainous watershed in the Union Territory of Jammu and Kashmir during 2020. These include Esakiozephyrus icana, Spindasis ictis and Tajuria jehana. The information on their current extent and known occurrence will be helpful in updating the range distribution of butterflies in north-western Himalayas.

Key words: Elevational bands; lepidopteran fauna; mountainous landscapes; Neeru watershed; north-western Himalayas.

Abstract. La presente comunicación trata de tres especies de mariposas pertenecientes a la familia Lycaenidae y subfamilia Theclinae, registradas por primera vez en diferentes localidades en una cuenca montañosa en el Territorio de la Unión de Jammu y Cachemira durante 2020. Estas incluyen a Esakiozephyrus icana, Spindasis ictis y Tajuria jehana. La información sobre su presencia actual existente y conocida será útil para actualizar la distribución de las mariposas en el noroeste del Himalaya.

Palabras clave: Bandas de elevación; cuenca Neeru; fauna de lepidópteros; Himalaya noroccidental; paisajes montañosos.

It is noteworthy that the mountainous landscapes of Jammu and Kashmir though offering a wide variety of lepidopteran habitats have been least explored for butterflies (Sharma \& Sharma 2017). Neeru watershed, the part of upper Chenab catchment (Fig. 1) certainly positioned in the Oriental region (Price et al. 2003) comprises of low lying valleys, forested slopes, alpine rangelands and rugged rocky outcrops in different microclimatic regimes. The butterflies inhabiting these habitats show a variety of distributional patterns in different elevational bands. The region has quite recently emerged as a potential butterfly hotspot contributing several new species to the lepidopteran fauna of Jammu and Kashmir (Sharma \& Sharma 2018a, 2018b, 2020).

During an occasional three days butterfly survey along an elevational gradient from

Received 12 February 2021 / Accepted 15 April 2021 / Published online 23 April 2021

Responsible Editor: José Mondaca E. 
September 1-3, 2020, we encountered three new Lycaenid butterflies belonging to subfamily Theclinae, Esakiozephyrus icana (Moore, 1875), Spindasis ictis (Hewitson, 1865) and Tajuria jehana (Moore, 1884) earlier not recorded from the geographical limits of Jammu and Kashmir. The species were photographed and their identities were confirmed following Varshney \& Smetacek (2015), Kehimkar (2008, 2016), Smetacek (2016), Sondhi \& Kunte (2018), besides the expert-curated online portal, Butterflies of India website (https: / www. ifoundbutterflies.org/ ). The systematic account of the species is provided as per Varshney and Smetacek (2015).

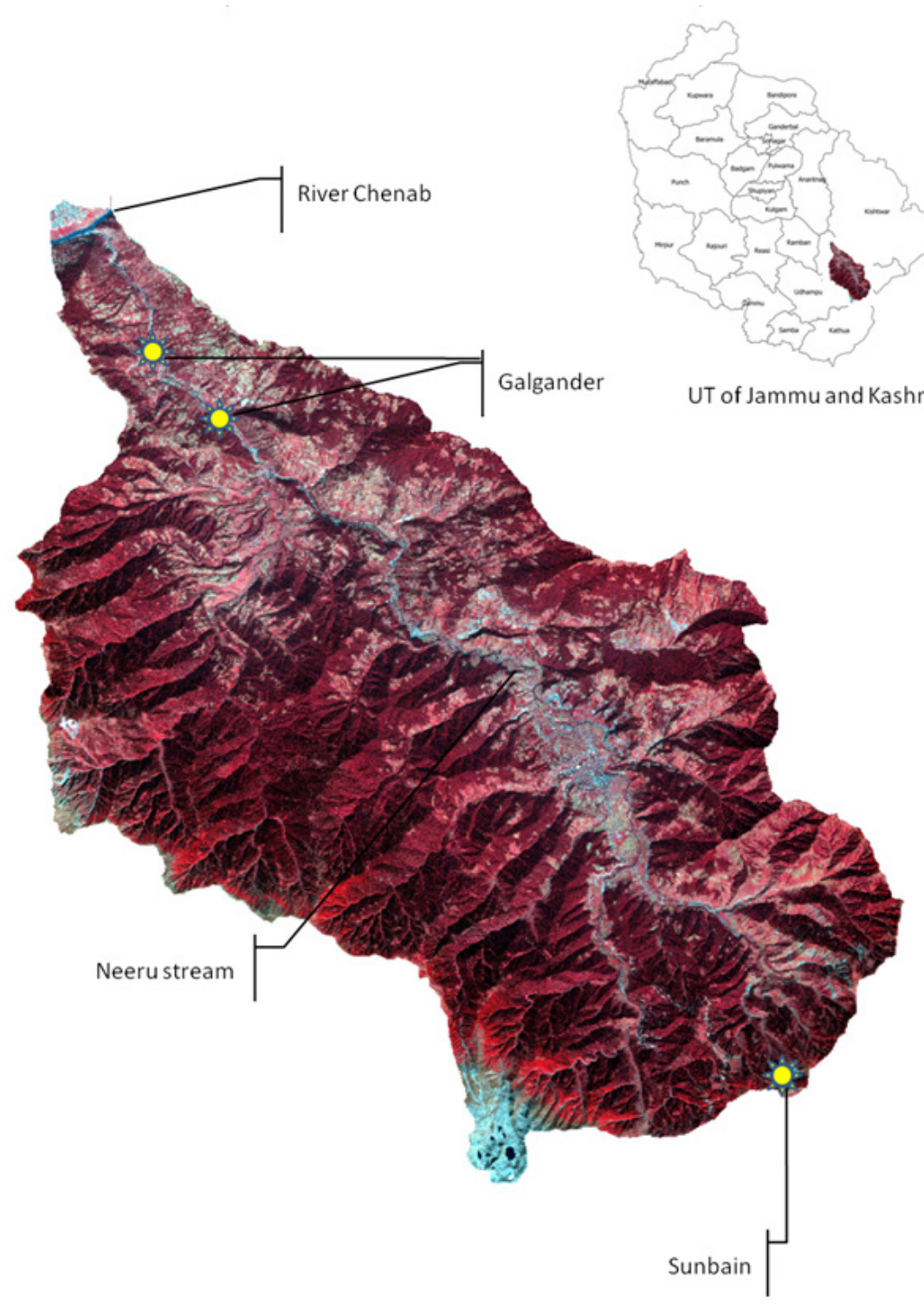

Figure 1. Study area (Neeru watershed) showing locations of new butterfly records (inset is the map of Union Territory of Jammu and Kashmir, India). / Área de estudio (cuenca Neeru) que muestra la ubicación de nuevos registros de mariposas (el recuadro es el mapa del Territorio de la Unión de Jammu y Cachemira, India). 


\section{Esakiozephyrus icana (Moore, 1875) (Dull-green Hairstreak)}

Current known occurrence until this reporting: India (Himachal Pradesh to Uttarakhand, Arunachal Pradesh), Nepal, Bhutan (Varshney \& Smetacek 2015; Kehimkar 2016; Singh 2016; Singh \& Sondhi 2016; van Gasse 2017; Sondhi \& Kunte 2018; Anonymous 2021).

Remarks. On a bright sunny afternoon of 1.ix.2020, we observed a couple of relatively small dark brownish butterflies nectaring on the floral spikes of Persicaria hydropiper (Delabre, 1800) along a mountain trek towards Sunbain, upper Bhaderwah $\left(32^{\circ} 53^{\prime} 41^{\prime \prime} \mathrm{N}\right.$ $75^{\circ} 46^{\prime} 40^{\prime \prime}$ E, c. $3246 \mathrm{~m}$ ), district Doda. The species was photographed and later identified as Esakiozephyrus icana (Moore, 1875) the Dull-green Hairstreak (Fig. 2) after consulting the keys and field guides (Kehimkar 2008; Varshney \& Smetacek 2015; Kehimkar 2016; Sondhi \& Kunte 2016, 2018), and the online web resources (https: / /www.ifoundbutterflies.org/ sp/3002/Esakiozephyrus-icana). The species rare in India (Kehimkar 2016; Sondhi \& Kunte 2018), has its western extent of occurrence restricted to Himachal Pradesh (Evans 1932; Sondhi \& Kunte 2018; Anonymous 2021). Our sighting of E. icana is first record of the species from the UT of Jammu and Kashmir. As the species is legally protected in India under Schedule II of the Wildlife (Protection) Act, 1972, the conservation of its habitat is necessitated.

\section{Spindasis ictis (Hewitson, 1865) (Common Shot Silverline)}

Current known occurrence until this reporting: India (Rajasthan northwards to Himachal Pradesh, eastwards to West Bengal, Odisha, Madhya Pradesh and southwards to Kerala), Pakistan, Sri Lanka (Varshney \& Smetacek 2015; Kehimkar 2016; Singh 2016; van Gasse 2017; Boruah et al. 2018; Singh \& Sondhi 2016; Flora et al. 2020; Kumar et al. 2020; Soman 2021).

Remarks. A silverline butterfly was spotted nectaring on flowers of Rubusniveus (Thunberg, 1813) near Galgander (33007'49" N - 75033'49" E, c. 920 m), district Doda on a sunny morning of 3.ix.2020. The individual was photographed in the field and identified as Spindasis ictis (Hewitson, 1865), Common Shot Silverline (Fig. 3) after consulting Kehimkar (2008, 2016), Varshney \& Smetacek (2015), Sondhi \& Kunte (2018) and online web resources (https: / / www.ifoundbutterflies.org// sp/877/Spindasis-ictis). The known western distribution of this species is from district Kangra of Himachal Pradesh (Soman 2021) and this reporting is thus the first from the Union Territory of Jammu and Kashmir.

\section{Tajuria jehana (Moore, 1884) (Indian Plains Blue royal)}

Current known occurrence until this reporting: India (Himachal Pradesh to eastern Himalayas, north east, south to peninsular India), Sri Lanka (Varshney \& Smetacek 2015; Kehimkar 2016; van Gasse 2017; Sondhi \& Kunte 2018; Sengupta et al. 2021).

Remarks. While doing field surveys during a late morning of 3.ix.2020, we observed a medium sized two tailed butterfly sitting on a rocky boulder near Neeru stream, Galgander (3307'35" N - 75034'01" E, c. 940 m), district Doda. The species was photographed and later identified as Tajuria jehana (Moore, 1884), Indian Plains Blue royal after consulting the keys and field guides (Kehimkar 2008; Varshney \& Smetacek 2015; Kehimkar 2016; Sondhi \& Kunte 2018), and the online web resources (https:/ / www.ifoundbutterflies.org/sp/513/ Tajuria-jehana). The species had earlier been recorded by one of the authors on 18.viii.2019 from Surinsar (32046'41" N - 75002'01" E, c. 596 m) district Jammu (Figs. 4, 5). Uncommon 
in India (Kehimkar 2016; Sondhi \& Kunte 2018), the western distribution of the species is up to Himachal Pradesh (Sondhi \& Kunte 2018; Sengupta et al. 2021) and thus a new record for UT of Jammu and Kashmir.

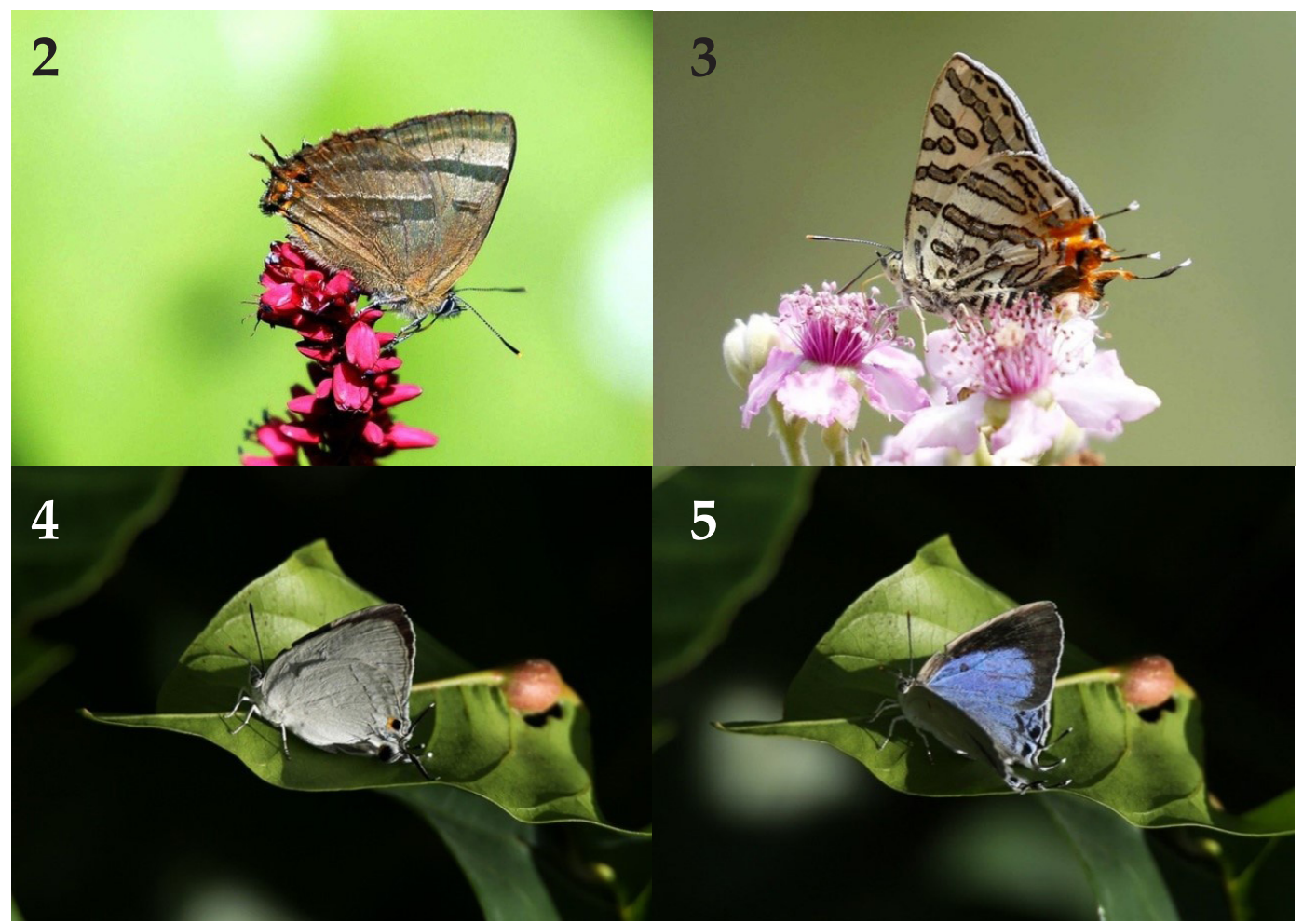

Figures 2-5. New Lycaenidae records from Jammu and Kashmir, India. 2. Esakiozephyrus icana, 3. Spindasis ictis, 4-5. Tajuria jehana. / Nuevos registros de Lycaenidae de Jammu y Cachemira, India. 2. Esakiozephyrus icana, 3. Spindasis ictis, 4-5. Tajuria jehana.

\section{Acknowledgements}

Rector, Bhaderwah Campus, University of Jammu is duly thanked for providing the administrative support during this study. The authors gratefully acknowledge Department of Wildlife Protection, Govt. of Union Territory of Jammu and Kashmir for their technical support. Authors express their gratitude to Dr. Dinesh Singh and Mr. Anil Thakar for their support during field surveys.

\section{Literature Cited}

Anonymous (2021) Esakiozephyrus icana (Moore, [1875]) - Dull-green Hairstreak. Kunte, K., S. Sondhi, and P. Roy (Chief Editors). Butterflies of India, v. 3.06. Indian Foundation for Butterflies. http:/ / www.ifoundbutterflies.org/sp/3002/Esakiozephyrus-icana

Boruah, B., Das, G.N., Payra, A., Gogoi, M.J., Dash, S.K., Tamuly, T., Sethy, J., Mishra, R.K. and Rout, S.D. (2018) Assessment of butterfly (Lepidoptera, Rhopalocera) diversity in Manchabandha and Budhikhamari reserve forest, Mayurbhanj, Odisha, India. Asian Journal of Conservation Biology, 7(1), 51-65.

Evans, W.H. (1932) The Identification of Indian Butterflies-2nd Edition. Bombay Natural History Society, Bombay, 454 pp. 
Flora, J.S., Tiple, A.D., Sengupta, A. and Padwad, S.V. (2020) Butterfly (Lepidoptera: Rhopalocera) fauna of Jabalpur City, Madhya Pradesh, India. Journal of Threatened Taxa, 12(11): 16607-16613. https: / / doi.org/10.11609/jott.4168.12.11.16607-16613

Kehimkar, I. (2008) The Book of Indian Butterflies. Bombay Natural History Society, Oxford University Press, Mumbai, 497 pp.

Kehimkar, I. (2016) BNHS Field Guides, Butterflies of India. Bombay Natural History Society, Oxford University Press, Mumbai, 506 pp.

Price, T.D., Zee, J., Jamdar, K. and Jamdar, N. (2003) Bird species diversity along the Himalayas; a comparison of Himachal Pradesh with Kashmir. Journal of the Bombay Natural History Society, 100(2-3): 394-409.

Sengupta, A., Nitin, R. and Sharan, V. (2021) Tajuria jehana Moore, [1884] - Plains Blue Royal. Kunte, K., S. Sondhi, and P. Roy (Chief Editors). Butterflies of India, v. 3.06. Indian Foundation for Butterflies. http:/ / www.ifoundbutterflies.org/sp/513/Tajuria-jehana

Kumar, S., Singh, R.S. and Singh, P. (2020) New records of one-spot grass yellow Eurema andersonii Moore (Lepidoptera: Pieridae) and common shot silverline Spindasis ictis Hewitson (Lepidoptera: Lycaenidae) from Kumaon region of Uttarakhand, India, Journal of Entomology and Zoology Studies, 8(4): 536-539.

Sharma, S. and Sharma, N. (2017) New butterfly records from the Jammu Shiwaliks, Jammu \& Kashmir, India. Journal of Threatened Taxa, 9(10): 10856-10859. https: / / dx.doi. org/10.11609/jot.3180.9.10.10856-10859

Sharma, S. and Sharma, N. (2018a) New lycaenid butterfly records from Jammu \& Kashmir, India. Journal of Threatened Taxa, 10(7): 11984-11987. https://dx.doi.org/10.11609/ jot.4046.10.7.11984-11987

Sharma, S. and Sharma, N. (2018b) New nymphalid butterfly records from Jammu \& Kashmir, India. Journal of Threatened Taxa, 10(11): 12602-12606. http://dx.doi. org/10.11609/jot.3874.10.11.12602-12606

Sharma, S. and Sharma, N. (2020) On the rediscovery and new additions of Skippers (Lepidoptera: Papilionoidea: Hesperiidae) from Jammu and Kashmir, India. Revista Chilena de Entomología, 46(4): 591-599. https:/ / doi.org/10.35249/ rche.46.4.20.05

Singh, A.P. and Sondhi, S. (2016) Butterflies of Garhwal, Uttarakhand, Western Himalayas, India 8(4): 8666-8697. http:/ / dx.dof org/10.11609/jot.2254.8.4.8666-8697

Singh, A.P. (2016) Moist temperate forest butterflies of western Bhutan. Journal of Threatened Taxa, 8(3): 8596-8601. http: / / dx.doi.org/10.11609/jott.2297.8.3.8596-8601

Smetacek, P. (2016) A Naturalist's Guide to the Butterflies of India, Pakistan, Nepal, Bhutan, Bangladesh and Sri Lanka. John Beaufoy Publishing Ltd., United Kingdom, 176 pp.

Soman, A. (2021) Spindasis ictis (Hewitson, 1865) - Common Shot Silverline. Kunte, K., S. Sondhi, and P. Roy (Chief Editors). Butterflies of India, v. 3.06. Indian Foundation for Butterflies. http: / / www.ifoundbutterflies.org/sp/877/Spindasis-ictis

Sondhi, S. and Kunte, K. (2016) Butterflies (Lepidoptera) of the Kameng Protected Area Complex, western Arunachal Pradesh, India. Journal of Threatened Taxa, 8(8): 9053-9124. http: / / dx.doi.org/10.11609/jott.2984.8.8.9053-9124

Sondhi, S. and Kunte, K. (2018) Butterflies of Uttarakhand - A Field Guide. Bishen Singh Mahendra Pal Singh (Dehradun), Titli Trust (Dehradun), National Centre for Biological Sciences (Bengaluru) \& Indian Foundation of Butterflies (Bengaluru), $x+310$ pp.

van Gasse, P. (2017) Annotated checklist of the butterflies of the Indo-Burmese region. http: / / www.ifoundbuterfies.org / Checklists (accessed October 26, 2017)

Varshney, R.K. and Smetacek, P. (2015) A Synoptic Catalogue of the Butterflies of India. Butterfly Research Centre, Bhimtal. Indinov Publishing, New Delhi, ii+261 pp + 8 pl. 